\title{
Pengaturan Lalulintas Kereta Api di Stasiun Cicalengka untuk Mendukung Pengoperasian Jalur Ganda Kereta Api Bandung-Cibatu
}

\author{
(Railway Traffic Arrangement at Cicalengka Station to Support Bandung-Cibatu Double \\ Railway Track Operation)
}

\section{DiAN SETIAWAN M, RAHARDHITA LUTHFIANA DEVI P, SRI ATMAJA P ROSYIDI}

\begin{abstract}
Indonesian Railway Authority plans to build a double railway track between Bandung-Cibatu which is currently the densest service line in Bandung Regency. Cicalengka Station is one of the major stations in this line service. This study aims to plan the train traffic arrangement at Cicalengka Station. The Conflict Rate Matrix Table was used as a simple simulation method to analyse the train journey route (formed, used, conflicted) and the degree of route usage against train frequency. The results showed that the Cicalengka Station on double track system would be passed by 98 passenger trains and planned to have two primary track (II and III) which are used for the direct train journey through the station. Track I, IV, V, and VI are the siding tracks that used for a railway stop. Cicalengka Station is also planned to have a route that is formed and is used each amounted to 10 routes (A to J). The conflict degree is 0.84 , and the degree of route usage against train frequency is 0.75 . Furthermore, it can be concluded that the percentage of non-conflicted route increased from $16 \%$ to $25 \%$.
\end{abstract}

Keywords: railway double track, station, train traffic arrangement, route, conflict degree

\section{PENDAHULUAN}

Provinsi Jawa Barat dikenal sebagai salah satu pusat perekonomian Indonesia dengan kekayaan utama di sektor pertanian dan perternakan. Salah satu daerah di Provinsi Jawa Barat penghasil terbesar dari sektor-sektor tersebut adalah Kabupaten Bandung yang dilintasi oleh jalur kereta api (KA) yang menjadi fokus pada penelitian ini. Akomodasi pengangkutan penumpang dan barang di Kabupaten Bandung kerap dilakukan melalui jalur darat menggunakan bus, truk dan KA. Namun, luas lahan operasional dan fasilitas utama maupun pendukung di beberapa terminal di Kabupaten Bandung umumnya tidak memenuhi standar. Selain itu permasalahan pada transportasi dilatarbelakangi oleh terjadinya pemekaran kota ke daerah-daerah kecil di sekitarnya secara tidak terstruktur dan tanpa adanya rencana sebelumnya sehingga menyebabkan terjadinya kemacetan di daerah perbatasan Kabupaten Bandung.
Sistem transportasi KA di Kabupaten Bandung sudah menjelma sebagai sarana transportasi umum utama, baik untuk pengangkutan barang maupun penumpang. Dengan keunggulan dan potensi moda transportasi KA, terlebih lagi untuk mendukung upaya pemerintah mengoptimalkan perekonomian Kabupaten Bandung, maka pemerintah berencana membangun jalur KA ganda lintas BandungCibatu yang merupakan lintas layanan terpadat di Kabupaten Bandung, sehingga nantinya diharapkan dapat meningkatkan jumlah KA yang beroperasi hingga dua kali lipat. Stasiun Cicalengka merupakan salah satu stasiun penting di lintas layanan Bandung-Cibatu tersebut yang direncanakan akan mengalami perubahan dan pengembangan akibat pembangunan jalur ganda dan peningkatan jumlah KA. Peningkatan jumlah KA yang melintas di stasiun Cicalengka berdampak pada perlunya pembaharuan pengaturan lalulintas KA sehingga dapat menjamin keselamatan dan kelancaran pengoperasian sistem perkeretaapian di lintas Bandung-Cibatu. 
Berdasarkan latar belakang yang telah disampaikan di atas, maka penelitian ini bertujuan untuk merencanakan pengaturan lalulintas KA di Stasiun Cicalengka yang meliputi rute-rute perjalanan KA yang dapat terbentuk, terpakai, berkonflik, dan derajat pembebanan rute terhadap frekuensi KA di Stasiun untuk mendukung operasional KA di jalur ganda lintas layanan Bandung-Cibatu.

Hasil penelitian ini menjadi sangat penting karena dapat digunakan lebih lanjut untuk menyusun langkah-langkah optimalisasi pola operasi jalur KA ganda di lintas layanan Bandung-Cibatu (Gambar 1).

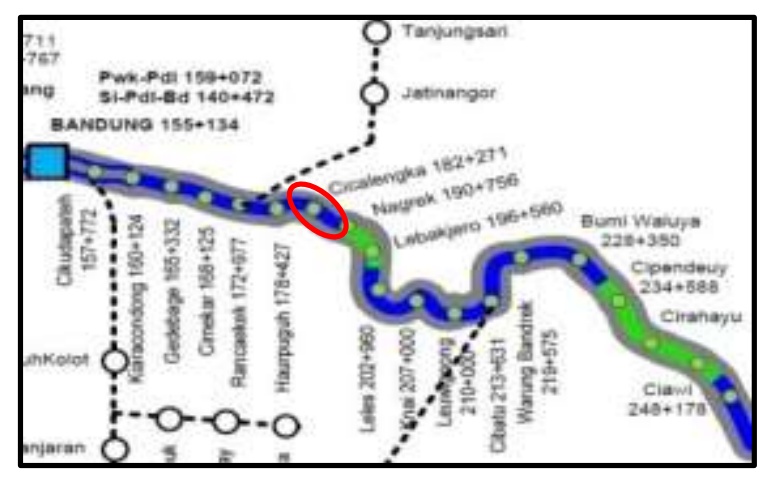

GAMBAR 1.Lokasi Studi

(Sumber: Kementerian Perhubungan, 2015)

\section{MetOdOLOGI}

Penelitian ini dilakukan melalui survei lapangan dan survei instansional untuk mendapatkan data sekunder yang digunakan sebagai dasar analisis pengaturan lalulintas KA di Stasiun Cicalengka. Data tersebut diantaranya adalah data lokasi, kelas, fungsi, jenis, dan kegiatan stasiun; gambar tata letak jalur stasiun eksisting (saat jalur tunggal); gambar tata letak jalur stasiun untuk jalur ganda (peningkatan tata letak jalur); data KA yang melintas di stasiun (nomor KA dan rute KA); serta prediksi frekuensi KA lintas bandung-cibatu tahun 2030. Pengaturan lalulintas KA di stasiun Cicalengka dilakukan berdasarkan tata letak jalur stasiun rencana untuk jalur ganda (6 jalur) sebagai acuan analisis rute terbentuk (berdasarkan konfigurasi jalur dan wesel), rute terpakai (berdasarkan rute yang dilewati oleh perjalanan KA yang melintas langsung tanpa berhenti maupun perjalanan KA yang berhenti untuk kegiatan naik-turun penumpang) dan rute konflik (Self correlation, Convergen, Divergen, dan Crossing). Analisis rute-rute perjalanan KA yang dapat terbentuk, terpakai, dan berkonflik tersebut juga dilakukan dengan metode simulasi sederhana menggunakan Tabel Matriks Derajat Konflik (TMDK). Sedangkan derajat pembebanan rute terhadap frekuensi perjalanan KA diperoleh dengan memasukkan jumlah KA ke dalam Tabel Matriks Derajat Konflik (TMDK) sesuai dengan rute yang dilewati oleh tiap-tiap KA. Selanjutnya dilakukan perbandingan antara nilai derajat konflik rute (CR) dan derajat pembebanan rute terhadap frekuensi perjalanan KA untuk mengetahui tingkat efisiensi pengaturan lalulintas KA di stasiun (prosentase pergerakan KA yang tidak berkonflik (ef)).

\section{Rute-rute Perjalanan Kereta Api di Stasiun}

Menurut Setiawan (2015), rute dari setiap perjalanan KA dapat mengalami konflik di jalur tunggal maupun di jalur ganda. Adapun ruterute perjalanan KA meliputi:

1. Rute yang dapat terbentuk sesuai dengan konfigurasi jalur dan wesel di stasiun.

2. Rute yang terpakai oleh perjalanan KA dari total rute yang dapat terbentuk.

3. Derajat konflik rute (Conflict Rate) merupakan derajat terjadinya konflik antara tiap-tiap rute yang terpakai.

Menurut Setiawan (2015), kompleksitas faktor yang mempengaruhi metode perhitungan kapasitas stasiun tidak dapat dilepaskan dari perhitungan Conflict Rate untuk memperoleh nilai dari kapasitas sistem interlocking. Kapasitas sistem interlocking dapat diinvestigasi dengan metode simulasi sederhana menggunakan Tabel Matriks Derajat Konflik (TMDK). Proses tersebut di atas juga merupakan salah satu bagian penting dalam konsep kajian pola operasi jaringan KA selain jenis pengangkutan KA, jumlah KA per hari, panjang rangkaian KA untuk penumpang dan barang, kecepatan maksimum KA penumpang dan barang, lokasi stasiun, fungsi stasiun, kelas stasiun, jenis dan kegiatan di stasiun, petak jalan dan petak blok, kapasitas lintas, dan tata letak jalur di stasiun (Setiawan, 2016).

Dengan simulasi menggunakan TMDK, derajat konflik rute dapat ditentukan sebagai perbandingan antara jumlah kombinasi rute-rute yang berkonflik dengan jumlah total kombinasi rute-rute yang dapat terbentuk. Jenis rute konflik yang dimaksud adalah sebagai berikut:

a. Self correlation (S), yaitu konflik antara 2 rute perjalanan KA yang bergerak pada rute yang sama atau tumpang-tindih. 


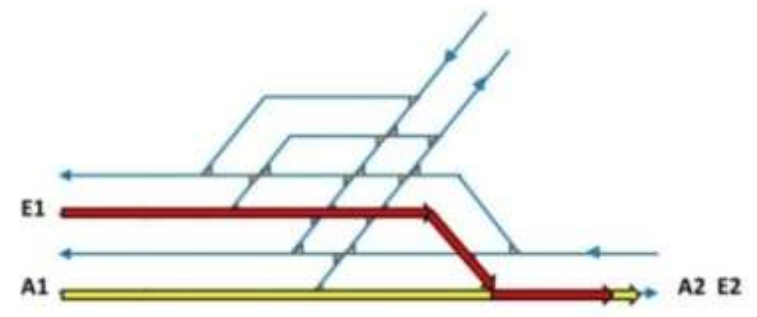

GAmbar 2. Rute Convergen A-E

(Sumber: Pachl, 2004)

b. Convergen (C), yaitu konflik antara 2 rute perjalanan KA yang bergerak dari asal yang berbeda, tetapi dengan tujuan yang sama (Gambar 2).

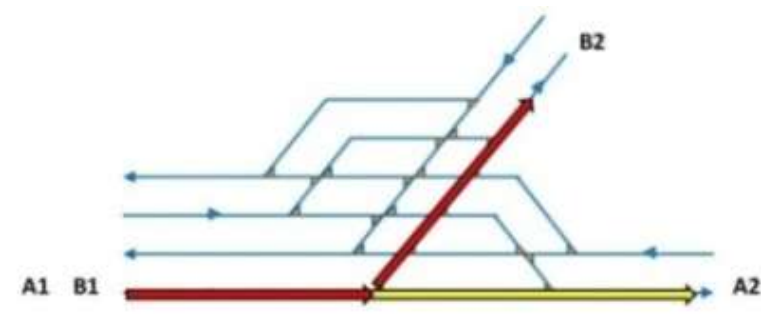

GAMBAR 3. Rute Divergen A-B

(Sumber: Pachl, 2004)

c. Divergen (D), yaitu konflik antara 2 rute perjalanan KA yang bergerak dari asal yang sama, tetapi dengan tujuan yang berbeda (Gambar 3).

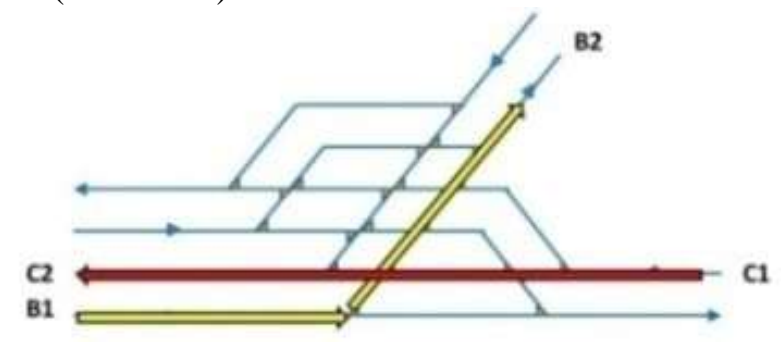

GAMBAR 4. Rute Crossing B-C

(Sumber: Pachl, 2004)

d. Crossing (X), yaitu konflik antara 2 rute perjalanan KA yang bergerak dari asal dan tujuan yang berbeda (Gambar 4).

\section{HASIL DAN PEMBAHASAN}

Menurut Peraturan Pemerintah Republik Indonesia Nomor 72 Tahun 2009 tentang Lalu Lintas dan Angkutan Kereta Api, pengoperasian KA pada jalur ganda atau lebih seharusnya menggunakan sistem jalur kanan. Namun pengoperasian KA pada jalur ganda juga dapat menggunakan jalur kiri jika dalam keadaan tertentu. KA yang berjalan langsung di stasiun dilewatkan pada jalur KA lurus, kecuali di stasiun persimpangan untuk ke jalur tertentu, di peralihan jalur KA dari jalur ganda ke jalur tunggal dan sebaliknya, atau di stasiun yang tidak memiliki jalur lurus sesuai dengan peraturan pengamanan setempat.

\section{Lokasi dan Kelas Stasiun}

Informasi mengenai Stasiun Cicalengka dapat dilihat pada Tabel 1 berikut:

TABEL 1.Lokasi stasiun

\begin{tabular}{cccc}
\hline $\begin{array}{c}\text { Nama } \\
\text { Stasiun }\end{array}$ & $\begin{array}{c}\text { Letak } \\
(\mathrm{KM})\end{array}$ & $\begin{array}{c}\text { Fungsi } \\
\text { Stasiun }\end{array}$ & $\begin{array}{c}\text { Kelas } \\
\text { Stasiun }\end{array}$ \\
\hline Cicalengka & $182+271$ & $\begin{array}{c}\text { Stasiun } \\
\text { Penumpang }\end{array}$ & Sedang \\
\hline
\end{tabular}

Stasiun Cicalengka merupakan stasiun KA kelas II (kelas sedang) dengan jalur eksisting berjumlah 3 jalur (Gambar 5).

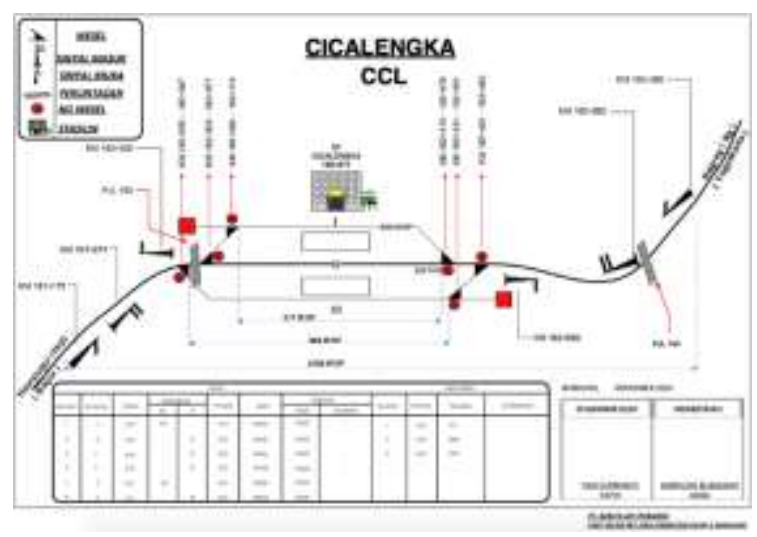

GAMBAR 5. Tata Letak Jalur di Stasiun Cicalengka Eksisting (Sumber: PT. KAI Daerah Operasi II Bandung, 2015)

\section{Fungsi, Jenis, dan Kegiatan Stasiun}

Stasiun adalah tempat KA berhenti, berangkat, bersilang, menyusul atau disusul dan langsir, serta dapat berfungsi untuk naik turun penumpang dan/atau memuat bongkar barang, yang dikuasai oleh seorang kepala yang bertanggung jawab penuh atas urusan perjalanan KA dan langsiran, yang dilengkapi dengan fasilitas pengoperasian.

Menurut Peraturan Menteri Perhubungan Nomor: PM. 33 Tahun 2011 tentang Jenis, Kelas, dan Kegiatan di Stasiun Kereta Api, stasiun KA merupakan prasarana KA sebagai tempat pemberangkatan dan pemberhentian KA. Stasiun Cicalengka merupakan stasiun yang khusus melayani angkutan penumpang dan juga stasiun yang melayani operasi KA. Stasiun penumpangmerupakan stasiun KA 
untuk keperluan naik-turun penumpang. Stasiun operasi merupakan stasiun KA untuk keperluan pengoperasian KA. Umumnya stasiun ini hanya melayani khusus angkutan penumpang.

\section{Perancangan Tata Letak Jalur Kereta Api di Stasiun Cicalengka}

Menurut Ratna Sari, et.al (2017) Stasiun Cicalengka yang saat ini memiliki 3 jalur eksisting (1 jalur raya dan 2 jalur sayap), di masa yang akan datang direncanakan akan memiliki 2 jalur raya (jalur II dan jalur III d), 4 jalur sayap (jalur I, jalur IV, jalur V dan VI), dan 4 jalur luncur seperti yang dapat dilihat pada Gambar 6.

\section{Pengaturan Lalulintas}

Perkiraan volume lalu lintas KA di Daerah Operasi II Bandung pada tahun 2030 tidak banyak berubah dibandingkan dengan Grafik Perjalanan Kereta Api (GAPEKA) pada tahun 2015, namun terdapat penambahan frekuensi yang signifikan untuk KA perkotaan (Ekonomi
Bandung Raya) dari 21 KA menjadi 54 KA (lihat Tabel 2).

Berdasarkan GAPEKA per 1 April 2015 dapat dilihat bahwa terdapat KA penumpang yang melintas di Stasiun Cicalengka baik perjalanan dari Stasiun Haurpugur ke Stasiun Nagreg dan sebaliknya, serta terdapat perjalanan KA dari dan menuju Stasiun Cicalengka. Berdasarkan data sekunder dari PT. KAI Daop II Bandung, telah diperoleh rangkuman data lalu lintas KA yang telah diperbarui sebagai data lalu lintas Stasiun Cicalengka rencana pada tahun 2030 (Tabel 2).

KA penumpang yang tidak singgah di Stasiun Cicalengka direncanakan langsung melintasi stasiun tersebut melalui kedua jalur raya, yaitu Jalur II dan Jalur III. Selain melayani perjalanan langsung bagi KA tersebut di atas, Stasiun Cicalengka juga menjadi tempat pemberhentian sementara untuk beberapa KA sebelum melanjutkan perjalanan, yang direncanakan akan melintasi jalur sayap, yaitu jalur I, IV, V, dan VI.

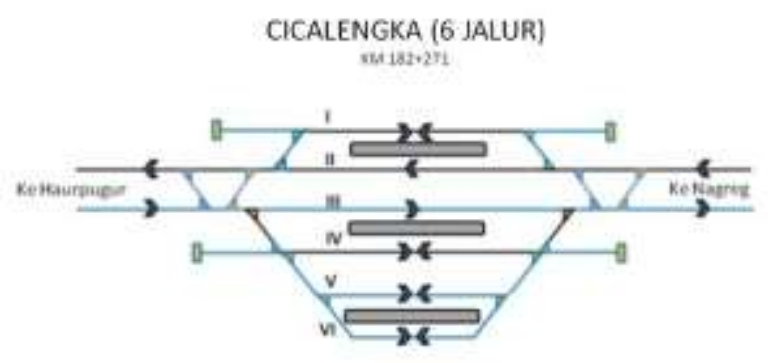

GAMBAR 6. Rencana Tata Letak Jalur Stasiun Cicalengka (Sumber: Ratna Sari, et. al, 2017)

TABEL 2. Prediksi Frekuensi Kereta Api Lintas Bandung-Cibatu Tahun 2030

\begin{tabular}{clcc}
\hline \multicolumn{3}{c}{ Lintas Bandung-Cibatu Tahun 2030 } \\
No & $\begin{array}{c}\text { Nama Kereta } \\
\text { Api }\end{array}$ & GAPEKA 2015 & $\begin{array}{c}\text { Prediksi Frekuensi } \\
\text { Kereta Api } \\
\text { (s.d 15 Tahun) }\end{array}$ \\
\hline 1 & Argo Wilis & $2 \mathrm{KA}$ & $4 \mathrm{KA}$ \\
\hline 2 & Turangga & $2 \mathrm{KA}$ & $4 \mathrm{KA}$ \\
\hline 3 & Lodaya & $4 \mathrm{KA}$ & $8 \mathrm{KA}$ \\
\hline 4 & Malabar & $2 \mathrm{KA}$ & $4 \mathrm{KA}$ \\
\hline 5 & Mutiara Selatan & $2 \mathrm{KA}$ & $4 \mathrm{KA}$ \\
\hline 6 & Pasundan & $2 \mathrm{KA}$ & $4 \mathrm{KA}$ \\
\hline 7 & Kahuripan & $2 \mathrm{KA}$ & $4 \mathrm{KA}$ \\
\hline 8 & $\begin{array}{l}\text { Kutojaya } \\
\text { Selatan }\end{array}$ & $2 \mathrm{KA}$ & $8 \mathrm{KA}$ \\
\hline 9 & Serayu & $2 \mathrm{KA}$ & $54 \mathrm{KA}$ \\
\hline 10 & $\begin{array}{l}\text { Ekonomi } \\
\text { Bandung Raya }\end{array}$ & $21 \mathrm{KA}$ & \\
\hline 54 ber: PT. KAI Daerah Operasi II Band & & \\
\hline
\end{tabular}

Sumber: PT. KAI Daerah Operasi II Bandung, 2015 
Rute Perjalanan dan Derajat Pembebanan Rute terhadap Frekuensi Kereta Api

1. Rute terbentuk

Pada penelitian ini, Stasiun Cicalengka direncanakan akan memiliki 6 jalur dan memiliki 10 rute yang dapat terbentuk berdasarkan konfigurasi jalur dan wesel seperti dijelaskan sebagai berikut:

a. Rute A (melewati jalur III/jalur raya) merupakan rute KA yang berasal dari Stasiun Haurpugur menuju Stasiun Nagreg dan difungsikan bagi perjalanan KA penumpang tanpa pemberhentian atau perjalanan langsung menuju ke Stasiun Nagreg. Selain itu jalur ini juga dapat digunakan sebagai rute bagi KA yang berhenti tanpa persilangan (lihat Gambar 7).

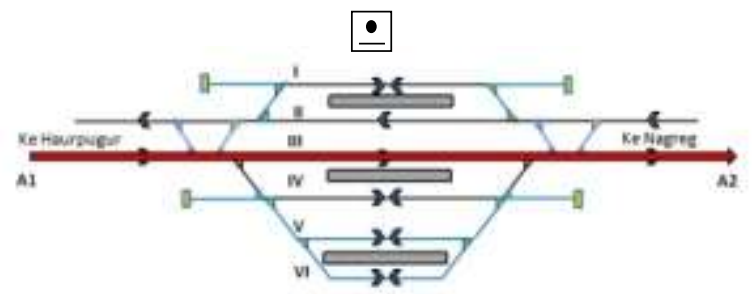

GAMBAR 7.Rute A di Stasiun Cicalengka

b. Rute B (jalur IV/jalur sayap) merupakan rute KA yang berasal dari Stasiun Haurpugur menuju Stasiun Nagreg, difungsikan bagi perjalanan KA penumpang dengan operasi pemberhentian seperti Kereta Api Lokal Ekonomi Bandung Raya dan Lodaya (lihat Gambar 8).

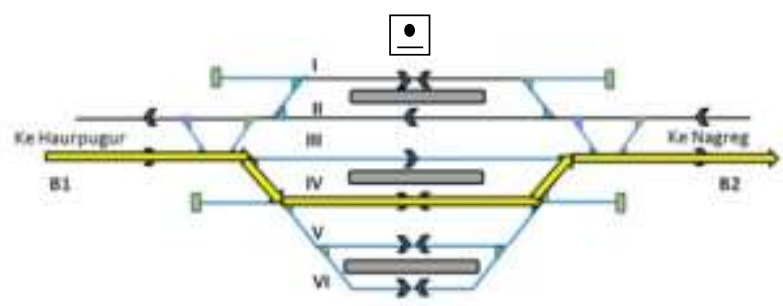

GAMBAR 8.Rute B di Stasiun Cicalengka

c. Rute C (jalur V/jalur sayap) merupakan rute KA yang berasal dari Stasiun Haurpugur menuju Stasiun Nagreg, difungsikan bagi perjalanan KA penumpang dengan operasi pemberhentian seperti Kereta Api Lokal Ekonomi Bandung Raya dan Lodaya (lihat Gambar 9).

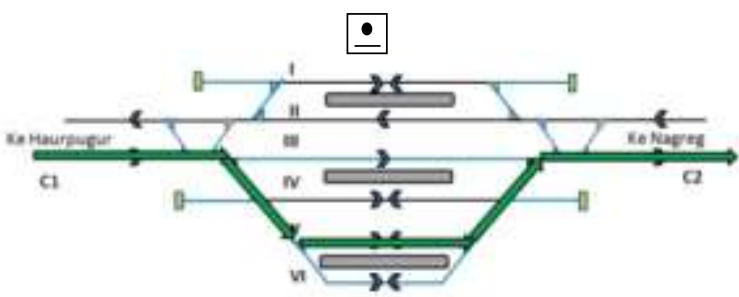

GAMBAR 9. Rute C di Stasiun Cicalengka

d. Rute D (jalur VI/jalur sayap) merupakan rute KA yang berasal dari Stasiun Haurpugur menuju Stasiun Nagreg, difungsikan bagi perjalanan KA penumpang dengan operasi pemberhentian seperti Kereta Api Lokal Ekonomi Bandung Raya (lihat Gambar 10).

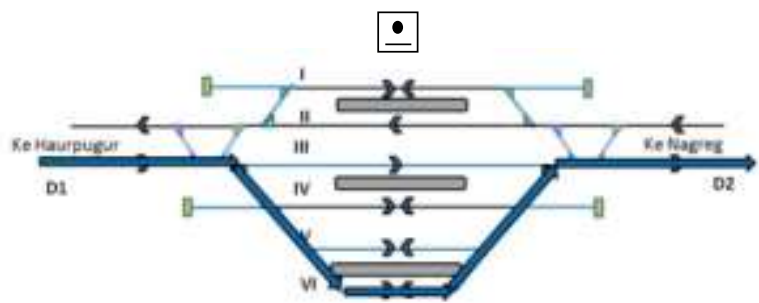

GAMBAR 10.Rute D di Stasiun Cicalengka

e. Rute E (jalur I/jalur sayap) merupakan rute KA yang berasal dari Stasiun Haurpugur menuju Stasiun Nagreg, difungsikan bagi perjalanan KA penumpang dengan operasi pemberhentian seperti Kereta Api Lokal Ekonomi Bandung Raya (lihat Gambar 11).

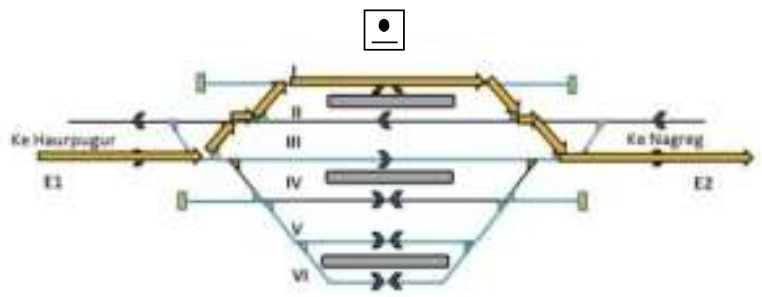

GAMBAR 11.Rute E di Stasiun Cicalengka

f. Rute F (jalur II/jalur raya) merupakan rute KA yang berasal dari Stasiun Nagreg menuju Stasiun Haurpugur, difungsikan bagi perjalanan KA penumpang tanpa pemberhentian di Stasiun Cicalengka atau perjalanan langsung menuju ke Stasiun Haurpugur, dan juga sebagai rute bagi KA yang berhenti tanpa persilangan, yaitu Kereta Api Lokal Ekonomi Bandung Raya, Malabar, Serayu Pagi, dan Kutojaya Selatan (lihat Gambar 12). 


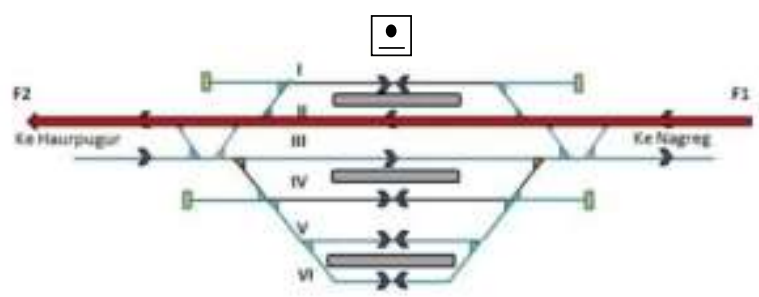

GAMBAR 12.Rute F di Stasiun Cicalengka

g. Rute G (Jalur I/jalur sayap) merupakan rute KA yang berasal dari Stasiun Nagreg menuju Stasiun Haurpugur, difungsikan bagi perjalanan KA penumpang dengan operasi persinggahan Kereta Api Lokal Ekonomi Bandung Raya (lihat Gambar 13).

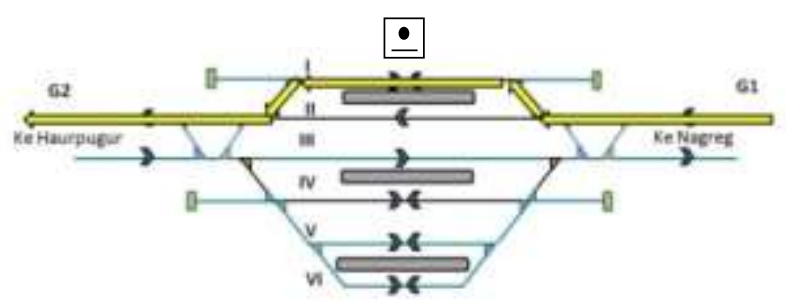

GAMBAR 13.Rute G di Stasiun Cicalengka

h. Rute H (jalur IV/jalur sayap) merupakan rute KA yang berasal dari Stasiun Nagreg menuju Stasiun Haurpugur, difungsikan bagi perjalanan KA penumpang dengan operasi pemberhentian seperti Kereta Api Lokal Ekonomi Bandung Raya dan Malabar yang mengarah dari Stasiun Nagreg, dan berhenti di Stasiun Cicalengka selama beberapa menit, kemudian melanjutkan perjalanannya kembali menuju arah Stasiun Haurpugur (lihat Gambar 14).

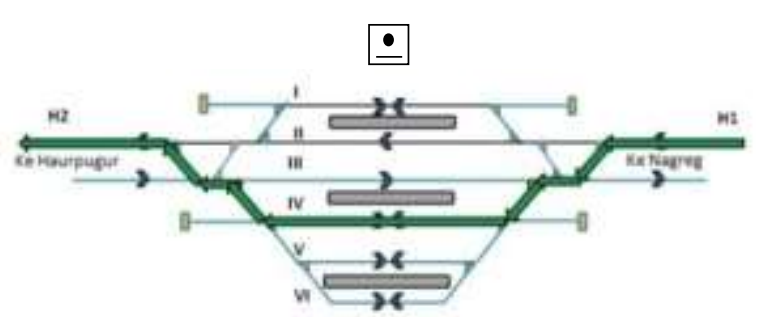

GAMBAR 14.Rute H di Stasiun Cicalengka

i. Rute I (jalur V/jalur sayap) merupakan rute KA yang berasal dari Stasiun Nagreg menuju Stasiun Haurpugur, difungsikan bagi perjalanan KA penumpang dengan operasi pemberhentian, dan dilewati Kereta Api Serayu Pagi dan Kereta Api Ekonomi Bandung Raya yang berasal dari Stasiun Nagreg menuju arah Stasiun Haurpugur (lihat Gambar 15).

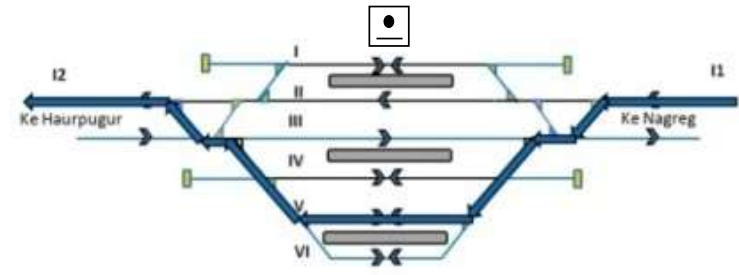

GAMBAR 15.Rute I di Stasiun Cicalengka

j. Rute J (jalur VI/jalur sayap) merupakan rute KA yang berasal dari Stasiun Nagreg menuju Stasiun Haurpugur,difungsikan bagi perjalanan KA penumpang dengan operasi pemberhentian, dan dilewati Kereta Api Ekonomi Bandung Raya dan Kutojaya Selatan yang berasal dari Stasiun Nagreg langsung menuju ke Stasiun Haurpugur.

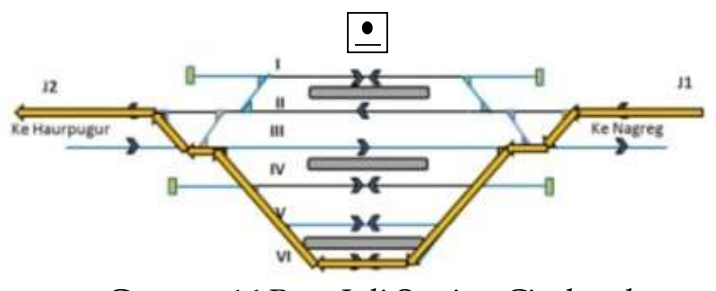

GAMBAR 16.Rute J di Stasiun Cicalengka

2. Rute terpakai

Perencanaan rute terpakai pada Stasiun Cicalengka didasarkan pada GAPEKA per 1 April 2015 untuk Daerah Operasi II Bandung namun dengan jumah KA sesuai dengan prediksi untuk tahun 2030. Data tersebut digunakan sebagai dasar pertimbangan dalam pemilihan rute (lihat Tabel 3).

TABEL 3. Rute Terpakai Rencana di Stasiun Cicalengka

\begin{tabular}{|c|c|c|}
\hline Rute & $\begin{array}{c}\text { Jumlah } \\
\text { Kereta } \\
\text { Api }\end{array}$ & Nomor Kereta Api \\
\hline A & 22 & $\begin{array}{l}184,206,226,228,180,6, \\
178,222,8,132,224,100, \\
424,429,82,50,182,134, \\
204,102,86, \text { dan } 52\end{array}$ \\
\hline B & 7 & $\begin{array}{l}376,406,416,398,84,412, \\
\text { dan } 404\end{array}$ \\
\hline $\mathrm{C}$ & 6 & $\begin{array}{l}80,410,400,382,402, \text { dan } \\
394\end{array}$ \\
\hline $\mathrm{D}$ & 7 & $\begin{array}{l}\text { 407, } 388,418,419,380,392, \\
\text { dan } 384\end{array}$ \\
\hline $\mathrm{E}$ & 7 & $\begin{array}{l}386,396,408,417,378,390, \\
\text { dan } 414\end{array}$ \\
\hline $\mathrm{F}$ & 22 & $\begin{array}{l}225,177,181,81,227,49, \\
426,423,183,428,83,51, \\
131,101,221,133,79,203, \\
5,85,7, \text { dan } 179\end{array}$ \\
\hline
\end{tabular}




\begin{tabular}{ccl}
\hline Rute & $\begin{array}{c}\text { Jumlah } \\
\text { Kereta } \\
\text { Api }\end{array}$ & \multicolumn{1}{c}{ Nomor Kereta Api } \\
\hline G & 7 & $\begin{array}{l}387,397,393,403,385,395, \\
\text { dan } 405\end{array}$ \\
\hline H & 7 & $\begin{array}{l}409,99,379,389,399,401, \\
\text { dan } 415\end{array}$ \\
\hline I & 7 & $\begin{array}{l}377,427,420,421,381,425, \\
\text { dan } 223\end{array}$ \\
\hline J & 6 & $\begin{array}{l}411,422,391,413,383, \text { dan } \\
205\end{array}$ \\
\hline & (Sumber: Hasil Penelitian, 2017)
\end{tabular}

(Sumber: Hasil Penelitian, 2017)

3. Derajat konflik rute

Derajat konflik rute (Conflict Rate) dapat ditentukan sebagai prosentase perbandingan antara jumlah kombinasi rute-rute berkonflik dengan jumlah total kombinasi rute-rute yang terbentuk berdasarkan notasi asal dan tujuan rute.

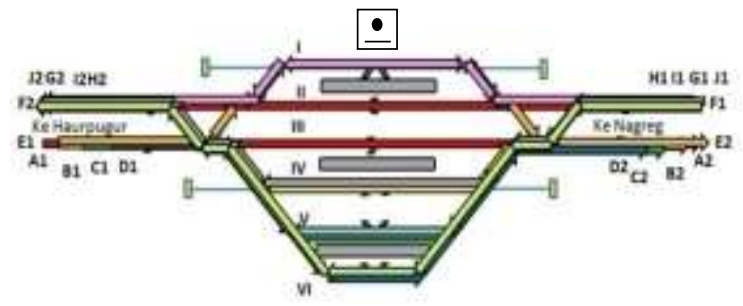

GAMBAR 17. Notasi asal dan tujuan rute Stasiun Cicalengka

TABEL 4.Tabel matriks derajat konflik (TMDK) pada Stasiun Cicalengka

\begin{tabular}{ccccccccccc}
\hline Rute & A & B & C & D & $\mathbf{E}$ & $\mathbf{F}$ & $\mathbf{G}$ & $\mathbf{H}$ & $\mathbf{I}$ & $\mathbf{J}$ \\
\hline A & S & D & D & D & D & N & N & X & X & X \\
\hline B & D & S & D & D & D & N & N & X & X & X \\
\hline C & D & D & S & D & D & N & N & X & X & X \\
\hline D & D & D & D & S & D & N & N & X & X & X \\
\hline E & D & D & D & D & S & X & X & X & X & X \\
\hline F & N & N & N & N & X & S & D & D & D & D \\
\hline G & N & N & N & N & X & D & S & D & D & D \\
\hline H & X & X & X & X & X & D & D & S & D & D \\
\hline I & X & X & X & X & X & D & D & D & S & D \\
\hline J & X & X & X & X & X & D & D & D & D & S \\
\hline \multicolumn{7}{c}{ (Sumber: Hasil Penelitian, 2017) } & &
\end{tabular}

Keterangan:

$\mathrm{N}$ : No conflict

D : Diverging conflict

$\mathrm{C}$ : Converging conflict

$\mathrm{X}$ : Crossing conflict

$\mathrm{S}:$ Self correlation

Berdasarkan table 4, diperoleh total 100 kombinasi rute-rute yang terbentuk, dengan rincian diantaranya 16 kejadian tanpa konflik atau No Conflict $(\mathrm{N}=16), 40$ kejadian konflik Divergen $(\mathrm{D}=40), 34$ kejadian konflik Crossing $(\mathrm{X}=34)$, dan 10 kejadian konflik Self Correlation $(\mathrm{S}=10)$ yang kemudian selanjutnya dapat digunakan untuk menghitung derajat konflik rute (CR) dengan perhitungan:

$$
\begin{aligned}
\mathrm{CR} & =\frac{(100-16)}{100} \times 100 \% \\
& =84 \% \\
& =0.84
\end{aligned}
$$

Sehingga prosentase pergerakan KA yang tidak saling berkonflik (ef) ialah:

$$
\text { ef } \begin{aligned}
& =100 \%-\mathrm{CR} \\
& =100 \%-84 \% \\
& =16 \% \\
& =0.16
\end{aligned}
$$

Menurut perhitungan Conflict Rate (CR) pada Stasiun Cicalengka di atas, diperoleh nilai derajat konflik rute sebesar 0.84 atau sekitar $84 \%$ rute perjalanan KA saling berkonflik dan $16 \%$ pergerakan KA tidak saling berkonflik (ef).

4. Derajat pembebanan rute ditentukan dengan menggunakan susunan table matriks derajat konflik (TMDK) yang sama dengan sebelumnya, namun perhitungan dilakukan dengan turut memasukkan jumlah KA yang menggunakan masing-masing rute berkonflik tersebut.

TABEL 5.Derajat pembebanan rute di Stasiun Cicalengka

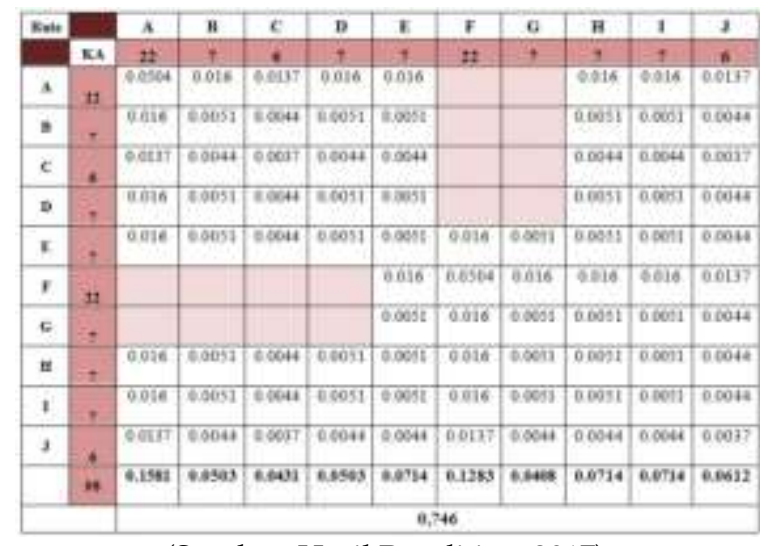

(Sumber: Hasil Penelitian, 2017)

Berdasarkan perhitungan di atas diperoleh nilai derajat pembebanan rute terhadap frekuensi perjalanan KA di Stasiun Cicalengka sebesar 0.75 (75\%). Nilai ini lebih kecil dibandingkan dengan nilai derajat konflik rute (CR dengan nilai $84 \%$ ) sehingga dapat disimpulkan bahwa terdapat 
peningkatan prosentase pergerakan KA yang tidak saling berkonflik (ef) dari semula 16\% menjadi $25 \%$.

\section{KESIMPULAN}

Berdasarkan hasil penelitian pada aspek-aspek pengaturan lalulintas KA di Stasiun Cicalengka untuk mendukung pengoperasian jalur ganda Bandung-Cibatu, maka dapat diambil beberapa kesimpulan sebagai berikut:

1. Stasiun Cicalengka pada sistem jalur ganda dilewati 98 KA penumpang. Stasiun Cicalengka direncanakan memiliki 2 jalur raya, yaitu jalur II yang merupakan jalur perjalanan KA dari Stasiun Nagreg menuju Stasiun Haurpugur dan jalur III yang merupakan jalur perjalanan KA dari Stasiun Haurpugur menuju Stasiun Nagreg dan juga jalur yang direncanakan akan dilewati oleh KA penumpang yang tidak berhenti di stasiun ini. Jalur I, IV, V, dan VI merupakan jalur sayap sebagai tempat pemberhentian KA sementara.

2. Stasiun Cicalengka direncanakan memiliki rute yang terbentuk dan rute yang terpakai masing-masing berjumlah 10 rute. Rute $\mathrm{A}$ akan dilewati $22 \mathrm{KA}$, rute $\mathrm{B}$ akan dilewati 7 $\mathrm{KA}$, rute $\mathrm{C}$ akan dilewati $6 \mathrm{KA}$, rute $\mathrm{D}$ akan dilewati $7 \mathrm{KA}$, rute $\mathrm{E}$ akan dilewati $7 \mathrm{KA}$, rute $\mathrm{F}$ akan dilewati $22 \mathrm{KA}$, rute $\mathrm{G}$ akan dilewati $7 \mathrm{KA}$, rute $\mathrm{H}$ akan dilewati $7 \mathrm{KA}$, rute I akan dilewati $7 \mathrm{KA}$ dan rute $\mathrm{J}$ akan dilewati $6 \mathrm{KA}$ sehingga diperoleh derajat konflik rute sebesar 0.84 dan derajat pembebanan rute terhadap frekuensi perjalanan KA sebesar 0.75 .

3. Nilai derajat pembebanan rute terhadap frekuensi perjalanan KA di Stasiun Cicalengka lebih kecil dibandingkan dengan derajat konflik rute (CR) yang menandai bahwa terdapat peningkatan efisiensi pengaturan lalulintas KA.

\section{DAFTAR PUSTAKA}

Kementerian Perhubungan. (2015). Peta Jaringan Kereta Api Indonesia. Jakarta.

Pachl, J. (2004). Railway Operation and Control. $3^{\text {rd }}$ edition, VTD Rail
Publishing, Mountlake Terrace (USA) 2014, 284 p., 198 ill.

PT. KAI Daerah Operasi II Bandung. (2015). Grafik Perjalanan Kereta Api (GAPEKA) Stasiun Cicalengka. Bandung.

PT. KAI Daerah Operasi II Bandung. (2015). Prediksi Frekuensi Kereta Api Lintas Bandung-Cibatu Tahun 2030.

PT. KAI Daerah Operasi II Bandung. (2015). Tata Letak Jalur Stasiun Cicalengka. Bandung.

Ratna Sari, Intan Ayu. (2017). Perancangan Tata Letak Jalur di Stasiun Cicalengka Untuk Mendukung Operasional Jalur Kereta Api Ganda Cicalengka-NagregLebakjero. Tugas Akhir. Fakultas Teknik Universitas Muhammadiyah Yogyakarta.

Sekretariat Negara. (2009). Peraturan Pemerintah Republik Indonesia Nomor 72 Tahun 2009 tentang Lalu Lintas dan Angkutan Kereta Api. Lembaran Negara RI Tahun 2009, No. 72. Jakarta: Republik Indonesia.

Sekretariat Negara. (2011). Peraturan Menteri Perhubungan Republik Indonesia Nomor 33 Tahun 2011 Tentang Jenis, Kelas, dan Kegiatan di Stasiun Kereta Api. Lembaran Negara RI Tahun 2011, No. 33. Jakarta: Republik Indonesia.

Setiawan, Dian, M. (2015). Analisis Conflict Rate pada Perhitungan Kapasitas Sistem Interlocking yang Mempengaruhi Penyusunan Formulasi Kapasitas Stasiun. The $18^{\text {th }} \quad$ FSTPT International Symposium.Universitas Lampung.

Setiawan, Dian, M. (2016). Kajian Pola Operasi Jalur Ganda Kereta Api Muara Enim-Lahat. Jurnal Ilmiah Semesta Teknika Vol. 19 (2016). No. 1, 37-47. 
PENULIS:

\section{Dian Setiawan M}

Program Studi Teknik Sipil, Fakultas Teknik, Universitas Muhammadiyah Yogyakarta, Kabupaten Bantul, DIY.

Email: diansetiawanm@ft.umy.ac.id dian_setiawanm@yahoo.co.id

Rahadhita Luthfiana Devi P

Program Studi Teknik Sipil, Fakultas Teknik, Universitas Muhammadiyah Yogyakarta, Kabupaten Bantul, DIY.

Email: dhitalth@gmail.com

Sri Atmaja P Rosyidi

Program Studi Teknik Sipil, Fakultas Teknik, Universitas Muhammadiyah Yogyakarta, Kabupaten Bantul, DIY.

Email: atmaja.sri@gmail.com 